\title{
INTERCULTURAL COMMUNICATION COMPETENCE: AN INTERNATIONAL STUDENTS EXPERIENCE IN INDONESIA
}

\author{
Janette Maria Pinariya $^{1 *}$; Aldila Maharani Sutjipto \\ ${ }^{1,2}$ Faculty of Communication, Postgraduate Program, LSPR Communication \& Business Institute \\ Jl. K.H. Mas Mansyur No. Kav. 35, Karet Tengsin, Jakarta Pusat 10220, Indonesia \\ 1janette.mp@1spr.edu; ${ }^{2}$ aldilamaharani92@gmail.com
}

Received: $02^{\text {nd }}$ February 2021/ Revised: $10^{\text {th }}$ March 2021/ Accepted: $15^{\text {th }}$ March 2021

How to Cite: Pinariya, J. M. \& Sutjipto, A. M. (2021). Intercultural communication competence: An international students experience in Indonesia. Humaniora, 12(2), 89-97. https://doi.org/10.21512/humaniora.v12i2.6999

\begin{abstract}
The research aimed to analyze the intercultural communication competence based on international students' experience in Indonesia and discussed how, in the globalization era, education had reached a new stage where the process of knowledge exchange had crossed national borders. However, educational institutions were not fully prepared to accommodate these modern needs. Although the study of intercultural communication was not new, concern for new cultural diversity had only received great attention lately, wherein the end, the Intercultural Communication Competence (ICC) in educational fields was still very low and must continue to be explored. The research applied a case and phenomenological study method with a descriptive qualitative approach. The data were gathered through semi-structured interviews and study literature. By analyzing the interactive multicultural building model, supported by the concept of intercultural communication and internationalization of higher education, the research results show that there are still inequalities and differences of opinion as well as an assessment of a three-perspective model that is used as the research focus. It consists of the affective process (intercultural sensitivity), cognitive process (intercultural awareness), and behavioral process (intercultural adroitness). Besides, there are various challenges that must be faced.
\end{abstract}

Keywords: intercultural communication competence, interactive multicultural building model, foreign students

\section{INTRODUCTION}

Globalization continues to bring various changes, advancements, and challenges at the same time. Over time, the distance separating various countries increasingly disappeared, making various cultures become closer than ever before and increasing the interaction between individuals within it (Luthfia, 2011; Luthfia, 2014). With the existing changes, people are required to have increasingly complex skills and knowledge in creating appropriate and effective interactions within diversity, whether it is in the form of ethnicity, race, religion, culture, and others (Neal et al., 2013; Barrett et al., 2014; Perry \& Southwell, 2011). Regarding this matter, there have been many studies conducted to deal with the existing problems. As a result, there is one special and important skill that is needed in dealing with cultural differences, namely
Intercultural Communication Competence (ICC) (Pinto, 2018; Penbek, Şahin, \& Cerit, 2012; Martin \& Nakayama, 2015).

ICC itself is defined by Penbek, Şahin, and Cerit (2012) as the ability to change one's knowledge, attitudes, and behavior to be open and flexible to other cultures. It has become an important skill that must be possessed by an individual to survive in a global society in this era. Huang et al. in Penbek, Şahin, and Cerit (2012) have also explained that a person who has the ability of intercultural competence can develop relational competence with people from different cultures, manage to solve complicated conflicts by moving around alternatives that arise as a result of cultural differences, and improve the ability to do business with counterparts from different cultures.

Holliday (2011) has explained that the majority of people consider language skills as the most crucial 
element in intercultural communication, but in reality, that element alone is not enough, since they also have to understand the 'silent language', such as distance, perception, facial expressions, body language, and others. This is where ICC plays an important role because intercultural communication competence today is not only discussing the ability to speak a foreign language but also the ability to find out as much information as possible about the other party to create effective communication. Chen and Starosta (1996) have said that the citizens of the twenty-first century must learn to see through people's eyes, hearts, and minds from cultures other than their own. Because of that, the development of ICC becomes one of the main concerns in all kinds of programs and activities, in various fields, including health, business, social, as well as education.

In the globalization era, education has reached a new stage where the process of knowledge exchange has crossed national borders; one of many proofs that could be seen is the rise of student exchange programs conducted by various countries (Chelliah et al., 2019; Findlay et al., 2011).

Most universities and social entities have implemented various international programs, including student exchanges. They are sending and receiving students from various countries to create short-term international experiences, where they could develop skills that will hopefully be able to guide them in today's global business world (Penbek, Şahin, \& Cerit, 2012). The global population of students studying in other countries doubled to 5 million in 2014 from 2,1 million in 2000, with a growth rate of 10 percent (the University of Oxford in Chelliah et al., 2019).

Indonesian universities themselves are currently also getting a lot of attention from international students. Based on Patdono Suwignjo, General Director of Institutional, Science, and Technology (in Astuti, 2017) statement, throughout 2016, there are 6.967 learning permits have been issued, in which the study permit is one of the main requirements for international students in Indonesia. The number of applications for study permits for international students here is experience increasing, to 150-500 applications every week. The Ministry of Research and Technology and Technology and Higher Education (in Arowana, 2016) targets the number of international students in Indonesia to reaching 20.000 in 2019.

The choice of a country by many international students can indeed be one of many proofs that the country excels in international competition. The presence of international students in a country becomes an essential element in higher education internationalization, which could help in creating diversity, facilitate cross-cultural understanding, create tolerance, increase research capacity, and help further development (Guo \& Chase, 2011; Maringe \& Foskett, 2012). Because of this, various countries compete to bring in foreign students to study in their countries. Indonesia's opportunity to bring in foreign students is also no less great than other countries (Abidin, 2017).
However, if there is nothing specifically designed, it will be challenging to obtain the expected target.

One of the most critical factors that are often being overlooked, including in Indonesia as a developed country while dealing with foreign students, is intercultural communication competence. The reason ICC plays an important role in the education fields, especially in student exchange programs, is because foreign students need to adapt to a new sociocultural system which is certainly different from their home country (Yu \& Wright, 2016; Wright \& Schartner, 2013; Gu, Schweisfurth, \& Day, 2010). As stated by Kim in Cai and Teng (2014), communication plays an important role during this adaptation process. Adaptation occurs through the communication interface between the stranger and the host milieu, just as the natives acquire their capacity to function in the society through communicative interactions throughout their lives. However, instead of that, educational institutions are not fully prepared to accommodate these modern needs. Although the study of intercultural communication is not new, concern for new cultural diversity has received significant attention lately, wherein the end of the ICC in educational fields is still very low and must continue to be explored and encouraged (Smakova \& Paulsrud, 2020; Fitriyah, Munir, \& Retnaningdyah, 2019; Irwandi, 2017).

This topic becomes increasingly important because student exchange programs should contribute more than just economic benefits (Gareis, 2012). As a host country, Indonesia must be able to provide a variety of experiences and values to foreign students. With its own global experience, Indonesia will get benefit from positive images and responses that are created based on foreign student's experience. In the end, they could play a crucial role in fostering productive relations with the host country, providing recommendations to their partners, and even the potential of becoming a connecting bridge between Indonesia and its home country in the future. ICC could become an advantage in organizing student exchange programs; meanwhile, these factors are often overlooked.

The important role of communication and interaction in the world of education, especially in creating good experiences for foreign students, has been discussed by various studies, which based on previous research, state of the art, Rohrlich and Martin in 1991; Searle and Ward in 1990 (in Gareis, 2012). Those are found that the main satisfaction factor of exchange students living in a country is the contact and relations with host citizens. Foreign students expect this interaction to have better language skills, improved academic performance, lower stress levels, and greater life satisfaction. Dziegielewska in 1988; Furnham and Alibhai in 1985 (in Jon, 2013) have also said that meaningful relationships with host citizens help the adaptation process and play an important role in enhancing the international image. Besides, Barger in 2004; Geelhoed, Abe, and Talbot in 2003; Nesdale and Todd in 2000; Parsons in 2010; Williams and Johnson in 2011 (in Jon, 2013) have explained in their research 
involving international and domestic students in the US and Australian higher education that the positive effects of their interactions on domestic students have a positive effect on educational, social, and cultural experiences. Unfortunately, this potential is often not being realized, and one of the most prominent complaints from students studying abroad is the lack of contact with host citizens. It is not uncommon for one third or more international students to report having no host friends at all (Gareis, 2012). Various studies have also found that domestic students can feel challenged and reluctant to interact with international students because of cultural differences, language barriers, biases, and pressures for academic performance (Jon, 2013). From this, it could be seen that the lack of intercultural communication competence has become the main cause.

To create good relations and develop ICC, researchers have found that university involvement is vital. Universities need to understand how to build an ICC and create comfort for foreign students. They need to provide not only knowledge but also personal experience and communication skills that are fun and productive for their participants. Making student exchange programs an activity that, despite its short duration, becomes a tool for creating positive change that can be remembered for a lifetime.

There have been many previous studies discussing the factors that influence country selection as an educational destination. However, research related to ICC awareness and its implementation is still very minimal, especially in developed countries. Based on these explanations, the researchers are interested to see further about Intercultural Communication Competence based on the experience of foreign students in Indonesia. The research aims to provide information related to ICC based on the foreign student's experience, the challenges faced, and how to overcome it. This is done as an effort to further evaluate the ICC in the context of education which is expected to contribute to the improvement of the competence among students by seeing the urgency and importance of the ICC's role in various sectors.

The research is supported by several theories and concepts. The first theory used is intercultural communication. According to Neuliep (2018), intercultural communication occurs wherever a minimum of two persons from different cultures or microcultures come together and exchange verbal and nonverbal symbols. It occurs within and between various interconnected contexts, including cultural, microcultural, environment, perceptual, and sociorelational contexts (Neuliep, 2018).

It is a communication activity between people with different beliefs, values, and norms, where all of the messages originate from a unique or specific cultural context (Devito in Nurhadi, Hendrawan, \& Ayutria, 2019). According to Effendy (2017), intercultural communication occurs in two forms, namely personal communication (communication that happens between two people) or group communication (communication that occurs between a person and a group or groups of people). Tuleja (2016) has also added by defining intercultural communication as the communication exchange between people who are different culturally. It examines how the specific cultural differences affect the interactions of the people engaged. While related to the intercultural communication function, Liliweri (2014) has explained several functions, including personal functions (stating social identity, expressing social integration, increasing knowledge) and social functions (supervision, bridging, value socialization, entertaining).

The next theory used in the research is intercultural communication competence. The study of ICC or intercultural communication is originated from political scientists and anthropologists work in the 1940-1950s (Chen \& Starosta, 1996). It is stated that only through competent intercultural communication can persons from different cultures communicate effectively and appropriately in the upcoming global society. Liu, Volcic, and Gallois (2014) have explained that intercultural communication occurs for every message that is produced by a member of one culture for consumption by members of another culture. Intercultural communication faces various problems and challenges because each member of culture certainly has a different way of communicating and thinking. As such, the ICC becomes a direction to analyze communicator's interpretations, motivations, and skills in intercultural communication.

After examining various approaches regarding ICC, an interactive-multicultural building model is found (Chen \& Starosta, 1996). This model is used to explain the processes that exist from three different perspectives that are equally important, inseparable, and form a picture of intercultural communication competence. This model aims to increase the ability to understand, appreciate, tolerate, and integrate cultural differences so that they are ready to become members of the world community (Chen \& Starosta, 1996).

It presents a transformational process of symmetrical interdependence, which is explained through three perspectives (Chen \& Starosta, 1996; Chen \& Starosta, 2000; Chen, 2010). The first perspective is the affective process (intercultural sensitivity). This perspective focuses on personal emotions or changes in feelings caused by certain situations, people, and environments. The four basic attributes that build this perspective are self-concept (the way a person sees himself), open-mindedness (the desire of individuals to express themselves openly and accept other people's explanations), non-judgmental attitudes (not having prejudice that can prevent someone from hearing other people during intercultural communication), and social relaxation (the ability to express anxiety or fear in intercultural communication). The second perspective is the cognitive process (intercultural awareness). This perspective emphasizes how people's way of thinking about an environment change by understanding the different characteristics of one's own culture. In 
this process, individuals are required to have selfawareness (the ability of individuals to monitor and make themselves aware) and cultural awareness (understanding of one's own culture and others that affect the way people think and behave). The last perspective is the behavioral process (intercultural adroitness). This perspective emphasizes how individuals act effectively in intercultural interactions. This perspective is closely related to communication skills, both verbally and non-verbally, to provide effective interaction. The attributes that build this perspective are message skills (the ability to use the language of a culture outside of its own culture), appropriate self-disclosure (willingness to disclose information openly and precisely during intercultural interactions), behavioral flexibility (ability to choose appropriate behavior in different contexts and situations), interaction management (the ability to talk alternately in a conversation, start, and end a conversation properly), and social skills (empathy, the ability to feel the same emotions as others and identity maintenance, maintaining the identity of the other person in interaction).

The last concept used in the research is the internationalization of higher education. Internationalization of higher education includes various strategies or activities designed to incorporate international education into the existing curriculum (Maringe \& Foskett, 2012) by focusing on improving the quality of education, recruiting international students, and developing partnerships. The internationalization of higher education itself is defined by Ellingboe (as cited by Gopal, 2011) as complex processes used to integrate international perspectives into higher education institutions by involving stakeholders as a response and adaptation to an increasingly diverse, global, and changing external environment. Zolfaghari and Sabran in Gopal (2011) have also described the internationalization of higher education as integration and infusion of an international dimension as a central part of a university's programs. Similar to that, Knight in Bedenlier and Zawacki-Richter (2015) has described it as the process of integrating an international dimension into the teaching/learning, research, and service functions of a university or college.

\section{METHODS}

The research applies use a case study and phenomenological study method with a descriptive qualitative approach to answer the problem formulation. This approach is considered to be able to provide an overview of concepts and designs to provide in-depth information about research topics (Rossman \& Ralis, 2017). Use so that the existing issues can be understood in more detail and utilized for evaluation purposes. Carried out with a case study, according to Yin (in Farquhar, 2012), it is defined as an empirical inquiry that investigates a contemporary phenomenon in depth and within its real-life context, especially when the boundaries between phenomenon and context are not clearly evident. It focuses on a particular unit which makes the analysis and results of the research more specific or in-depth (Creswell, 2014). Also, supported by the phenomenological study method, which is used to carefully examine the meaning of an individual's life experience and describe the fundamental essence of a phenomenon by engaging a small number of participants to make patterns and connections (Dimandja, 2017).

The research began in September 2019 until September 2020. The intercultural communication competence theory approach focuses on the interactive multicultural building model, which consists of three perspectives, namely the affective process, the cognitive process, and the behavioral process.

The research applies semi-structured interviews and study literature as data collection techniques. Interviews are conducted with a total of 17 interviews, which include ten international students (among them are Dutch, Germany, Lithuanian, Zimbabwean, and Malaysia), five university team representatives (among them are Indonesian, Phillippines, Rusia, Thailand, and Malaysia), and two classmates (both Indonesian), which are digitally recorded with permission. As for the literature study, the research gets data from various existing sources to strengthen and complement the information obtained from the interviews.

The validity of data interpretation is done through source triangulation by comparing data obtained through several sources. For data analysis techniques, the research uses Miles and Huberman's (in Afrizal, 2014) models divided into three stages, namely data codification, data presentation, and conclusions drawing.

\section{RESULTS AND DISCUSSIONS}

When humans face greater cultural diversity, intercultural communication competence becomes increasingly important. Only with this competence, people from diverse cultures able to fully understand each other. As an effort to find out this competency, research is conducted to see further about Intercultural Communication Competence (ICC) based on the experience of foreign students in Indonesia, the challenges they are faced, and how to overcome them.

The approaches to the study of intercultural communication competence discussed then lead to a three-perspective model that is used as the research focus. Figure 1 shows further discussion regarding the three models.

The first perspective is the affective process (intercultural sensitivity). This perspective focuses on personal emotions or changes in feelings caused by certain situations, people, and environments (Chen \& Starosta, 1996; Chen \& Starosta, 2000; Chen, 2010). Related to this, international students in Indonesia describe their ability to control their emotions and feelings caused by certain situations, people, and 


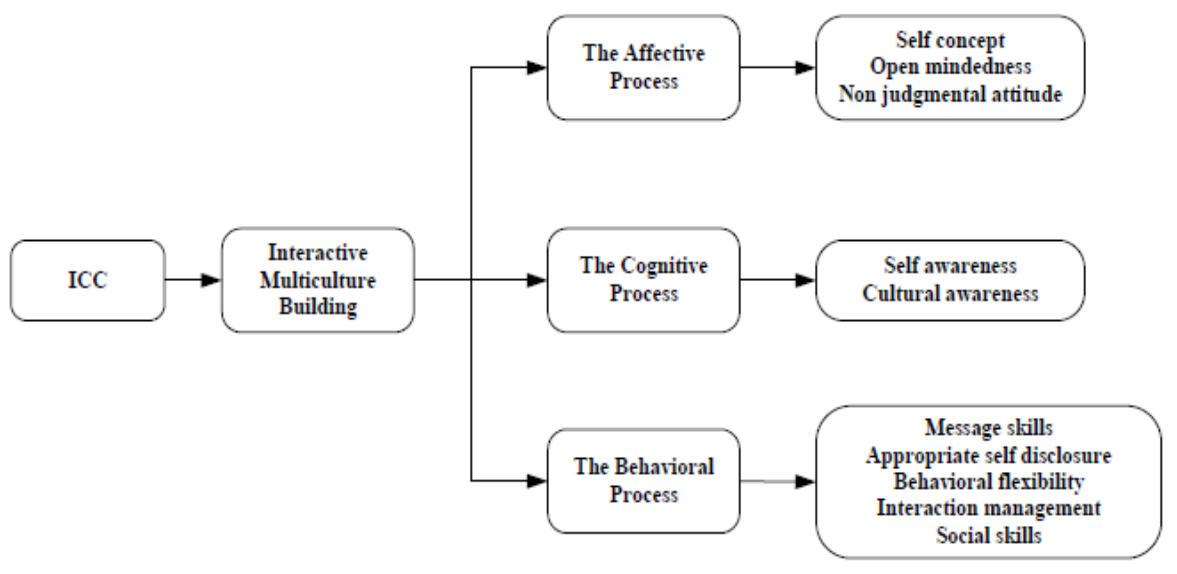

Figure 1 Research Focus

(Source: Chen \& Starosta, 1996; Researchers' processed data, 2020)

environments based on their experiences in doing student exchanges programs in Indonesia. Eight out of ten students interviewed claim to have this ability, where they explain that personal emotions or changes in feelings certainly happen all the time. However, when they encounter a variety of cultural differences when staying in another country, this feeling comes more often because few things are quite disturbing or different from their native culture. One student who is a Germany from Rhine Waal University (personal communication, February 5, 2020) discusses how she got uncomfortable when people in Jakarta often filmed her without permission. Something similar is also faced by a Lithuanian student from Hanze University of Applied Sciences, Groningen, The Netherland. She states that many Indonesians do not respect private space and do not even understand what private space is; people are always asking/shouting to take photos in every part of Jakarta (personal communication, January 22, 2020).

While in an academic context, a student from Universiti Teknologi MARA (UiTM) (personal communication, February 3, 2020) and Hanze University (personal communication, January 22, 2020) explain that their emotions and feelings changes often because they need to face new people, environments, and atmosphere in class. They think that classes in Indonesia are loud, where people are shouting or singing during the classes, and it is completely normal for the local students. Therefore, they find it unprofessional and disrespectful towards the lecturers and other students.

However, despite all of the changes and inconveniences they face, most of the student exchange participants that are interviewed acknowledge that they can still manage and handle the changes professionally. They show this by not getting angry or frustrated, but instead being friendly asked Indonesian to stop or explain that their culture is different. They also prove this ability by describing how they are able to maintain their facial expressions by not showing dislike when facing differences and difficulties.

Besides, two other students explain that they think they have the ability to control their emotions, but in reality, they have had many opportunities that prove they cannot do it. They realize the fact that understanding a culture indeed takes much patience, and coming from a country with a different kind of culture makes it hard to avoid the consideration of emotions in everyday life. German student from The Hague University (personal communication, January $17,2020)$ also adds that it takes him a while to realize that Indonesian people are very sensitive and feelings should be spared, which is a little frustrating at the beginning of his study journey.

The next perspective is the cognitive process (intercultural awareness). This perspective emphasizes a change in one's thoughts about an environment by understanding the different characteristics of people's culture (Chen and Starosta, 1996). Related to this perspective, all foreign students interviewed claim that they have the ability to change their way of thinking by understanding other's diversity and culture. Even they assume that this has become a necessity when they studied in other countries. This generally happens because they have had previous experience, whether it is because they are accustomed to living and developing in families or environments that come from various nationalities and living abroad experiences. The example is a statement from German students from Rhine Waal University.

"In order to communicate with another culture, you have to understand them. Having come from a country where diversity is so widespread, it was always in my nature to adapt to different cultures. My family alone is a mixture of Indonesian, Portuguese, Mozambican, and German; diversity is my life and always will be." (Personal communication, February 5, 2020) 
A Lithuanian student from Hanze University of Applied Sciences, Groningen, Netherlands also adds that to have this ability.

"Most of the times I try to "read between the lines' of what people are saying, try to imagine myself in their position if I want to understand culture and traditions of other people. Nonverbal communication is a cultural aspect and it is hard to lose that, so I do not mind that people are using one or another gestures towards myself, just because I know that someone can be offended by my own culture's non-verbal communication." (Personal communication, January 22, 2020).

The last perspective is the behavioral process (intercultural adroitness). This perspective emphasizes how individuals act effectively in intercultural interactions. This perspective is closely related to communication skills, both verbally and non-verbally, to provide effective interaction (Chen and Starosta, 1996). Similar to the previous perception, all foreign students that are interviewed acknowledge that they have the ability to communicate with people from other cultures, either verbally or non-verbally. This generally happens because even though there are many situations in Indonesia when people could not understand them or vice versa, they still could consistently deliver their needs. German student from The Hague University (personal communication, January 17, 2020) explains that when the English language does not work, they use nonverbal communication such as hands movement or facial expressions to explain and communicate. She also adds by state:

"Coming from a diverse family and country, I speak a total of seven languages. Over the course of learning that many languages, I also learnt that it is not enough to only learn words but to learn train of thought, actions, and gestures. Therefore, I find myself pretty comfortable falling into another's culture as long as I understand them; however, trying not to stereotype." (Personal communication, January 17, 2020)

Generally, all interviewed foreign students admit that they already have the competence to do intercultural communication based on the three perspectives. However, contrary statements come from four Indonesian classmates (Personal communication, February 18, 2020). They explain how based on their experience, they can see how student exchange participants often look annoyed and give an attitude towards a person that gets close to them. Indonesian friends also add that some foreign students look angry because Indonesian does not speak to the point and are not on time.

Besides the three perspectives, the research also discusses the challenges faced and how to overcome them in applying intercultural communication competence based on the international student's experience in Indonesia. Based on these statements, there are still inequalities and differences of opinion as well as an assessment of intercultural communication competencies, where foreign students think that they already have good intercultural communication skills, but on the other hand, host students have a different opinion. The difference in the assessment and standards then shows that training, information, and special programs are needed to create the same perception about ICC, as well as prepare students who will do the exchange program, both in their home and destination country.

The university team also explains that some of the obstacles faced by students participating in student exchange programs, in general, are regarding the language used by the teachers as an obstacle to academic factors. While barriers in social factors often happen because of the cultural differences that most of the time trigger misunderstandings. The team also acknowledges that most student exchange participants in Indonesia do not have close friends. While related to the weaknesses and strengths that the student exchange participants have, the team from various countries explains that foreign students from other Asian countries do not have problems or weaknesses because their cultures are generally similar to the Indonesian culture. While for students from other countries outside Asia, cultural awareness becomes their main weakness. Many students still do not know much about Indonesian culture and have some biases.

Meanwhile, related to the program that is carried out as an effort to overcome the existing problems, student exchange that is interviewed explains that there is no special program intended to prepare them. This is later confirmed by the universities, both from Indonesia and foreign university partners. However, some general activities or efforts are carried out, which are divided into online and conventional. As for online activities, the university utilizes the use of various social media to provide information regarding the exchange programs, including Instagram, Facebook postings, e-mail, and websites. As for offline activities, some activities that are carried out are briefing (predeparture \& during), a day-long orientation program that briefs about the country, city, language, culture, traditions, academic (info about academic activities, online sessions), campus posters, recommendations from their advisors, classroom visits, city tours, and student bodies.

It is also recognized by students, both Indonesian and foreign, that Indonesia's government roles and involvement related to the development of intercultural communication competencies are still considered passive. The Indonesian government only participates and directs students to know basic knowledge without being accompanied by specific communication skills training. With the assistance or participation of the government as the main policyholder, universities should be required or directed to form a special program 
related to the ICC, both aimed at foreign communities and Indonesia as its target audience. This could be part of the government strategy to help Indonesia become a ready and desirable education destination.

From this, it is once again proven that the ICC has not become a priority and received sufficient attention from various parties, such as students, universities, and the government. Because an effort to prepare foreign students has become a necessity, the researchers recommend that there should be a program like familiarization for intentional students, especially to understand the cultures and mastering intercultural communication competence at least in their destination country. To maximize the strategy used to develop ICC, assistance or support from various parties are needed, among them are the university as the main institution that provides services, foreign students as the main actors that are getting involved in intercultural communication activities, friends as assistants and interlocutors, and government as the facilitators who can play a vital role in determining the regulations which in various ways could affect the development of ICC.

Overall, besides all the problems faced, foreign students feel quite satisfied in choosing Indonesia as a study destination and recommend Indonesia to other students that will do the student exchange program in the future. However, they explain that this recommendation only applies if the students do not want to extend their university knowledge but experience adventure, communication, social, and personal skills in their lives. They recommend
Indonesia if the priority is traveling rather than gaining high-class education. Meanwhile, foreign university partners explain that the reason they chose Indonesia is due to several reasons, including diverse cultures, the potential to become a leading country in the region or globally, to offer more options to their students, to strengthen connections with ASEAN partners, safety, language, and currency.

\section{CONCLUSIONS}

With the existing changes, people are required to have increasingly complex skills and knowledge in creating appropriate and effective interactions within diversity. One particular and essential skill is needed in dealing with cultural differences, namely Intercultural Communication Competence (ICC). Therefore, the researchers are interested in further seeing ICC based on the experience of foreign students in Indonesia. The research aims to provide information related to ICC based on the foreign student's experience, the challenges faced, and how to overcome it.

The research has found that the majority of students assume that they have ICC both related to the elements in the affective, cognitive, and behavioral processes. This is proven by their statement based on various experiences they have encountered while staying in Indonesia. However, there are still inequalities and differences of opinion as well as an assessment of intercultural communication competencies, where contrary statements come from

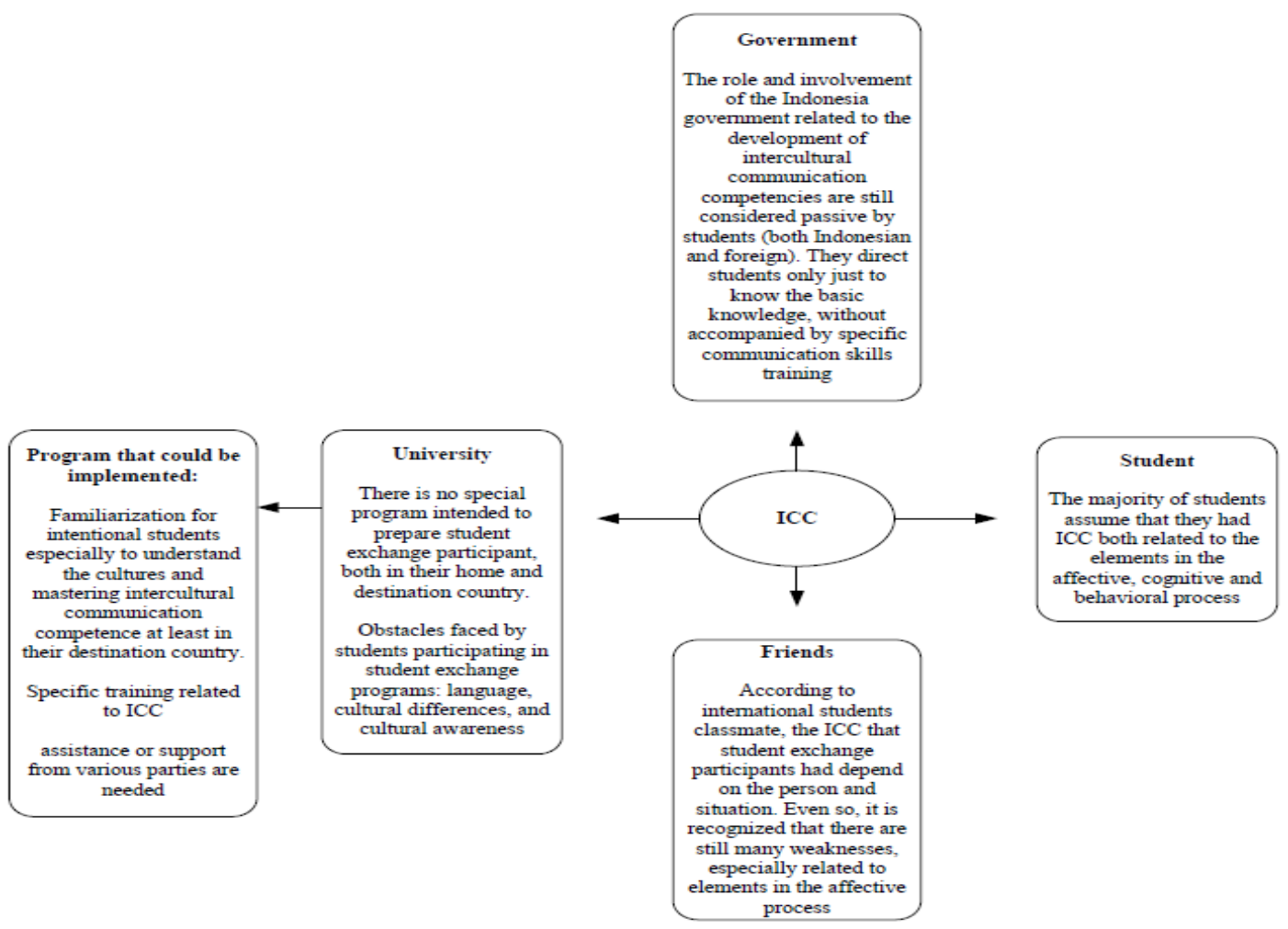

Figure 2 Conclusion

(Source: Author processed data, 2020) 
Indonesians who are the classmate. They explain how based on their experience, they could see how student exchange participants often look annoyed and give an attitude towards a person that gets close to them. Indonesian friends also add that some international students look angry because Indonesian does not speak to the point and are not on time.

The university team also explains that some of the obstacles faced by students participating in student exchange programs, in general, are regarding the language used by the teachers as an obstacle to academic factors. While barriers in social factors often happen because of the cultural differences that most of the time trigger misunderstandings. The team also acknowledges that most student exchange participants in Indonesia do not have close friends.

As a response to the existing problems, there is no special program intended to prepare students (both Indonesian and foreign) either by their home university, Indonesia university, or government. It is proven that the ICC has not become a priority and received sufficient attention from various parties yet.

Because an effort to prepare foreign students has become a necessity, there should be a program like familiarization for intentional students, especially to understand the cultures and master intercultural communication competence, at least in their destination country. To maximize the strategy used to develop ICC, assistance or support from various parties are needed, among them are the university as the main institution that provides services, foreign students as the main actors that are getting involved in intercultural communication activities, friends as assistants and interlocutors, and government as the facilitators who can play a vital role in determining the regulations which in various ways could affect the development of ICC. All of the conclusions can be seen in Figure 2.

These conclusions show that the ICC in Indonesia has not become a priority and received sufficient attention from various parties, both students, universities, and the government. Where consideration and challenges to this competence still need more review to achieve the maximum results in the context of intercultural communication. Since the research is only limited to the experiences of foreign students in Indonesia, more research on how the ICC works in different countries will be recommended.

\section{REFERENCES}

Abidin, H. (2017). Mahasiswa asing seputar Indonesia. Retrieved from https://nasional.sindonews.com/ $\mathrm{read} / 1214773 / 18 /$ mahasiswa-asing-1497830164.

Afrizal. (2014). Metode penelitian kualitatif. Jakarta: Rajagrafindo.

Arowana, A. (2016). Targetkan 20.000 mahasiswa asing, ini saran Kemenristek Dikti untuk semua perguruan tinggi. Retrieved from https://malangvoice.com/ targetkan-20-000-mahasiswa-asing-ini-saran- kemenristek-dikti-untuk-semua-perguruan-tinggi/.

Astuti, K. (2017). Izin belajar mahasiswa asing dipermudah. Retrieved from https://www.republika.co.id/berita/ pendidikan/dunia-kampus/17/05/12/optv7e361izin-belajar-mahasiswa-asing-dipermudah.

Barrett, M., Byram, M., Lázár, I., Mompoint-Gaillard, P., \& Philippou, S. (2014). Developing intercultural competence through education. CELT: A Journal of Culture, English Language, 5(1), 27-41.

Bedenlier, S., \& Zawacki-Richter, O. (2015). Internationalization of higher education and the impacts on academic faculty members. Research in ComparativeandInternationalEducation, 10(2), 185201. https://doi.org/10.1177/1745499915571707.

Cai, L., \& Teng, L. (2014). Towards cross-cultural adaptation of international students: A case study of Chinese students in Finland. BioTechnology: An Indian Journal, 10(9), 4047-4053.

Chelliah, S., Khan, M. J., Krishnan, T., Kamarulzaman, M. E. B. M., \& Goh, N. E. (2019). Factors influencing satisfaction and revisit intention among international exchange students in Malaysia. Journal of International Education in Business, 12(1), 111130. https://doi.org/10.1108/JIEB-07-2018-0026.

Chen, G. M. (2010). The impact of intercultural sensitivity on ethnocentrism and intercultural communication apprehension. Intercultural Communication Studies, 19(1), 1-9.

Chen, G. M., \& Starosta, W. J. (1996). Intercultural communication competence: A synthesis. Annals of the International Communication Association, 19(1), 353-383. https://doi.org/10.1080/23808985.1 996.11678935 .

Chen, G. M., \& Starosta, W. J. (2000). The development and validation of the intercultural sensitivity scale. Human Communication, 3(1), 1-15.

Creswell, J. W. (2014). Research design: Qualitative, quantitative, and mixed methods approaches. USA: Sage publications.

Dimandja, O. O. (2017). "We are not that different from you": A phenomenological study of undergraduate Muslim international student campus experiences. Doctoral Dissertation, USA: University of Colorado Colorado Springs.

Effendy, O. U. (2017). Ilmu komunikasi teori dan praktek. Bandung: Remaja Rosdakarya.

Farquhar, J. D. (2012). Case study research for business. London: Sage Publications Ltd.

Findlay, A. M., King, R., Smith, F. M., Geddes, A., \& Skeldon, R. (2011). World class? An investigation of globalization, difference and international student mobility. Transactions of the Institute of British Geographers, 37(1), 118-131. https://doi. org/10.1111/j.1475-5661.2011.00454.x.

Fitriyah, U., Munir, A., \& Retnaningdyah, P. (2019). Intercultural communicative competence in ELT: Lecturers' perception and practice. IJET (Indonesian Journal of English Teaching), 8(1), 62-71. https:// doi.org/10.15642/ijet2.2019.8.1.62-71.

Gareis, E. (2012). Intercultural friendship: Effects of home and host region. Journal of International and 
Intercultural Communication, 5(4), 309-328. https:// doi.org/10.1080/17513057.2012.691525.

Gopal, A. (2011). Internationalization of higher education: Preparing faculty to teach cross-culturally. International Journal of Teaching Learning in Higher Education, 23(3), 373-381.

Gu, Q., Schweisfurth, M., \& Day, C. (2010). Learning and growing in a "foreign" context: Intercultural experiences ofinternational students. Compare, 40(1), 7-23. https://doi.org/10.1080/03057920903115983.

Guo, S., \& Chase, M. (2011). Internationalization of higher education: Integrating international students into Canadian academic environment. Teaching in Higher Education, 16(3), 305-318. https://doi.org/1 $0.1080 / 13562517.2010 .546524$.

Holliday, A. (2011). Intercultural communication and ideology. California: SAGE Publications Inc.

Irwandi, I. (2017). Integrating intercultural communication competence in teaching oral communication skill. Proceedings of ISELT FBS Universitas Negeri Padang, 5, 246-252.

Jon, J. E. (2013). Realizing internationalization at home in Korean higher education: Promoting domestic students' interaction with international students and intercultural competence. Journal of Studies in International Education, 17(4), 455-470. https://doi. org/10.1177/1028315312468329.

Liliweri, A. (2014). Sosiologi dan komunikasi organisasi. Jakarta: Bumi Aksara.

Liu, S., Volcic, Z., \& Gallois, C. (2014). Introducing intercultural communication: Global cultures and contexts. London: Sage.

Luthfia, A. (2011). Kompetensi komunikasi antar budaya peserta pelatihan dari Indonesia di Australia. Humaniora, 2(1), 860-866. https://doi.org/10.21512/ humaniora.v2i1.3105.

Luthfia, A. (2014). Pentingnya kesadaran antarbudaya dan kompetensi komunikasi antarbudaya dalam dunia kerja global. Humaniora, 5(1), 9-22. https://doi. org/10.21512/humaniora.v5i1.2976.

Maringe, F., \& Foskett, N. (Eds.). (2012). Globalization and internationalization in higher education: Theoretical, strategic, and managementperspectives. London: A\&C Black.

Martin, J. N., \& Nakayama, T. K. (2015). Reconsidering intercultural (communication) competence in the workplace: A dialectical approach. Language and Intercultural Communication, 15(1), 13-28. https:// doi.org/10.1080/14708477.2014.985303.

Neal, S., Bennett, K., Cochrane, A., \& Mohan, G. (2013). Living multiculture: Understanding the new spatial and social relations of ethnicity and multiculture in England. Environment and Planning C: Government and Policy, 31(2), 308-323. https://doi.org/10.1068/ c11263r.

Neuliep, J. W. (2018). Intercultural communication: A contextual approach. Thousand Oaks, California: Sage Publications, Inc.

Nurhadi, Z. F., Hendrawan, H., \& Ayutria, D. F. (2019). Model komunikasi antar budaya keluarga mixed marriage di wilayah Budapest-Hungaria. Jurnal ASPIKOM, 3(6), 1140-1152. https://doi. org/10.24329/aspikom.v3i6.331.

Penbek, Ş., Şahin, D. Y., \& Cerit, A. G. (2012). Intercultural communication competence: A study about the intercultural sensitivity of university students based on their education and international experiences. International Journal of Logistics Systems and Management, 11(2), 232-252. https://doi. org/10.1504/IJLSM.2012.045425.

Perry, L. B., \& Southwell, L. (2011). Developing intercultural understanding and skills: Models and approaches. Intercultural Education, 22(6), 453-466. https://doi. org/10.1080/14675986.2011.644948.

Pinto, S. (2018). Intercultural competence in higher education: Academics' perspectives. On the Horizon, 26(2), 137-147. https://doi.org/10.1108/ OTH-02-2018-0011.

Rossman, G. B., \& Rallis, S. F. (2017). An introduction to qualitative research: Learning in the field. Thousand Oaks, California: Sage Publications.

Smakova, K., \& Paulsrud, B. (2020). Intercultural communicative competence in English language teaching in Kazakhstan. Issues in Educational Research, 30(2), 691-708.

Tuleja, E. A. (2016). Intercultural communication for global business: How leaders communicate for success. In Intercultural Communication for Global Business: How Leaders Communicate for Success (pp. 1-320). UK: Taylor \& Francis. https://doi. org/10.4324/9781315668642.

Wright, C., \& Schartner, A. (2013). "I can't .. I won't?" International students at the threshold of social interaction. Journal of Research in International Education, 12(2), 113-128. https://doi. org/10.1177/1475240913491055.

Yu, B., \& Wright, E. (2016). Socio-cultural adaptation, academic adaptation, and satisfaction of international higher degree research students in Australia. Tertiary Education and Management, 22(1), 49-64. https:// doi.org/10.1080/13583883.2015.1127405. 